\title{
Corporate dreams - Appropriate aspirations and the building of trust in annual reports
}

Henrik Rahm*, Lund University, Centre for Languages and Literature, Sweden Niklas Sandell, Lund University, Department of Business Administration, Sweden Peter Svensson, Lund University, Department of Business Administration, Sweden

*Corresponding author: henrik.rahm@nordlund.lu.se

\begin{abstract}
This paper argues that the corporate annual report is not only a document comprising retrospective accounts of financial position and performance, but also a text that points to the future by means of presenting dreams, aspirations and fantasies. However, these dreams are not to be seen as irrational deviations from the rationalistically oriented discourse of accounting. Quite to the contrary, the three corporate dreams identified in this study - the colonial dream, the evolutionary dream and the efficiency dream - are part of the ongoing self-narration of the company, in which it tries to display an allegiance to a set of appropriate aspirations that are considered legitimate in contemporary global capitalism. Drawing upon ideas from narrative theory, annual reports from 2005 to 2010 collected from NASDAQ OMX Stockholm have been analyzed with the purpose of understanding how corporate dreams are used in financial communication. These corporate dreams contribute, the paper argues, to the construction of legitimacy and trust.
\end{abstract}

Keywords

annual report, genre, goodwill, dreams, narratives, legitimacy, trust

\section{Introduction}

In this paper we investigate the visionary and future-oriented aspects of annual reports. More specifically, we shed light upon how annual reports offer an arena for corporate dreaming. This view contrasts considerably with how annual reports are commonly understood, viz. as retrospective texts whose function is to communicate the financial performance (income statement) and the financial position (balance sheet) of the company at the end of the year. The formal function of annual report is to provide owners, investors, analysts and other stakeholders with accurate information as input in the evaluation of the company and its performance. However, annual reports are also used for other communicative purposes such as branding and image building (Stanton \& Stanton 2002).

In annual reports there are few explicit possibilities for management to express dreams, visions and aspirations for the future. Dreaming about the future needs to take place elsewhere, e.g. in the form of investment plans and internal strategic documents. However, there are exceptions that merit attention. One exception is the introductory CEO letter in which ideas about the future can be formulated and dreams avowed. In this section, the company can speak - more freely than in other parts of the annual report - about hopes and dreams. Another section in the annual report allowing space for loose dreams and fantasies is the description of recognized goodwill, i.e. evaluations of the excess of the consideration over the net amounts of the identifiable assets acquired and liabilities assumed due to a corporate acquisition (International Financial Reporting Standard 3 (IFRS 3, p. 32). This section is the research object for this paper. At face value, the section where goodwill is described is not an evident space for formulation of future-oriented and visionary statements. However, if interpreted a bit closer the goodwill explanations often 
contain what we in this paper will refer to as corporate dreams, dreams that depict wishful visions about the future.

The aim of this paper is to contribute to the literature on the communicative functions of annual reports by means of investigating visionary and prospective aspects of financial communication. We will show how annual reports not only offer retrospective accounts of the financial status of the organization but also promote dreams and hopes about the future. However, these corporate dreams should not be conceived of as irrational, confused fantasies, rather as potentially legitimate responses to the institutional, ideological and discursive contexts in which the company operates. A public declaration of morally justifiable and legitimate dreams is, in itself, a performative act with direct and indirect consequences on corporate image, status and legitimacy. Dreaming "appropriate" dreams - in public - can be a way of presenting oneself as a trustworthy actor in the marketplace. Trust in the company is to a substantial extent an outcome of such discursive acts of legitimization. This study is an attempt to shed light upon one of these trust-building discursive acts.

Drawing upon narrative theory and discourse analysis we have analyzed goodwill formulations in annual reports collected from NASDAQ OMX Stockholm. Annual reports from 2005 to 2010 were analyzed and we identified three main corporate dreams: the colonial dream, the evolutionary dream, and the efficiency dream. In the remainder of the paper, we will argue that these dreams function as self-narratives, that is, narrated accounts of the company that contribute to the construction of a socially acceptable - and trustworthy - image of the company in question.

The paper is structured as follows. Firstly, we describe the genre of the annual report followed by a presentation of our study object: goodwill. In the next section we offer a brief review of the extant research on the communicative functions of annual reports, followed by a presentation of the research design. After this, a presentation of the findings - the three corporate dreams - follows. The paper ends with discussion and conclusions.

\section{The annual report}

Formally the annual report is the board of directors' report to the owners of the company (Ministry of Justice, 2005, chapter 7, paragraph 10). The specified purpose of the report is to provide valid information for the owners so as to enable informed decisions and accurate evaluations of the company, its board of directors and management. The annual report consists of two main parts, whereby the first part is unregulated and the second part is highly regulated through national and international rules and standards. It is here, in the last statutory part of the report, one can find the core of the annual report or at least what a few decades ago used to be the only content of an annual report - the income statement, the balance sheet, the cash-flow analysis and the notes.

Regulated as such, the annual report is primarily supposed to deal with the past, first and foremost the previous year. Successes and failures are explained and deviations from expectations are accounted for. Blame is attributed and credit is given (Rahm \& Sandell, 2016). In that sense the annual report can be seen as a part of an ongoing dialogue between the company and its environment, where the management of the company respond to the stakeholders' readings and concern (Brennan, Merkl-Davies, \& Beelitz, 2013; Lupu \& Sandu, 2017; Prakash \& Rappaport, 1977).

The text in the annual report belongs to the board of directors but mainly to the management of the company, which means that it is not a neutral description of reality (Arnold \& Oaks, 1998, p. 130). Rather, it is the description of reality from the perspective of one stakeholder, a description influenced by the fact that the evaluated writes the main part of the evaluation (Rahm \& Sandell, 2016). However, the annual report does not only provide the management's rule-governed description of the company. The story told, including the texts contextualizing the 
numbers of the annual report, contribute to shaping the events in the way the readers understand reality (Hines, 1988; Morgan, 1988). Explanations of goodwill is here an interesting case in point. Goodwill is an asset that originates from an acquisition. Hence, it is a past event that needs to be explained, but since it is part of an acquisition price that, at least in theory, has been determined by a net present value calculation of future cash-flows, the explanation of goodwill also requires an idea of the future.

\section{The case of goodwill}

When a company acquires another company and the consideration exceeds the value of the acquired company's identifiable net assets, the residual is termed goodwill. Over the years goodwill has been ascribed different meanings, from not being an asset of any value, being the value of the acquired company's reputation, being the value of abnormal returns - although this is more of a rationalization of the method of calculation than a standalone explanation - to being synergies from asset interaction, personnel and know-how, i. e. resources not recognisable as separate intangible assets (Gynther, 1969; Ma \& Hopkins, 1988; Sandell \& Svensson, 2016; Seetharaman, Balachandran \& Saravanan, 2004).Todaygoodwill is formally defined as:

An asset representing the future economic benefits arising from other assets acquired in a business combination that are not individually identified and separately recognised. (IFRS 3, Appendix A)

Hence, goodwill is a recognisable asset and according to IFRS 3 (paragraph 59-60, B64) recognised goodwill has to be reported and motivated by a qualitative description in the annual report of the acquiring company. This is a qualitative description of:

[...] the factors that make up the goodwill recognised, such as expected synergies from combining operations of the acquiree and the acquirer, intangible assets that do not qualify for separate recognition or other factors (IFRS 3, B64)

Thus, goodwill is described and motivated retrospectively as the acquisition is a historic event. But the goodwill paid for at the same time needs a prospective description and motivation as it deals with the future in terms of "future economic benefits" (IFRS 3) - through prognoses of revenues, cost savings and profits as a consequence of the acquisition. As goodwill is loaded with meaning in this prospective way, it is obvious that there are prospects, expectations or even hopes for the company. In this paper we argue that the descriptions of goodwill in the annual reports express hopes and desires which we label corporate dreams. One reason to use the word dream is that the assessments of the consequences of corporate acquisitions often are exaggerated (Gu \& Lev, 2011; King, Dalton, Daily, \& Covin, 2004; Moeller, Schlingemann \& Stultz, 2005; Wiklund \& Shepherd, 2009). Roll (1986) coined the hubris-hypothesis on acquisition of companies, which means that the management tends to overestimate their capability to generate profit by acquisitions, leading to high considerations. More interestingly however - goodwill descriptions offer a possibility for the management to formulate overarching dreams on the future path for the company. This is what interests us and will be the focus of our analyses. In the next section we will discuss previous research on the performative narrative and the genre of annual reports, which also affects the writing of goodwill. Then we describe the research design and the data studied. The three dreams identified are discussed and finally we reflect upon the status of these dreams in society, in terms of the overarching idea or ideology about corporate activities that these dreams represent and perhaps reproduce. 


\section{Previous research on the communicative function of annual reports}

The accounting language is often conceived of as a system of signification, symbols, esoteric terms and measures that needs to be read and interpreted by those who master this system of communication. These measures, symbols and numbers are however not only representations of past performance but also inscriptions that allow some decisions whereas others are made impossible (Vollmer, 2007, p. 580), i.e. the accounting language performs. In the annual report, the accounting language is interwoven with wordings, phrases and perspectives from another context, the everyday language, sometimes referred to as the natural language (Crowther, Carter, \& Cooper, 2006, p. 179). The everyday language has two interrelated functions. It is used to tell a story, as in the CEO-letter, in which the writer has to consider the accounting language. It is also used to verbalize the accounting language in the form of comments, words, phrases, arguments and explanations. However, the everyday language does not only describe things, i.e. words are not merely representations, rather words perform as they take part in the shaping of our understanding of business phenomena (Vollmer, Mennicken, \& Preda, 2009).

One stream of research within the field of discourse and performativity has focused on the role played by the everyday language on the promotion of plausible and legitimate representations of the company. For example, Arnold and Oaks (1998) studied the discursive construction of a crisis and its importance to render some solutions plausible and others unthinkable. Arnold and Oaks (1998, p. 146) argue that accounting, "as language, is not a passive reflection of events but plays an active role in constructing them". The everyday language of annual reports takes part in the production and reproduction of certain representations of business realities. In a similar vein, Power (2003, p. 379) states that accounting "shapes preferences, organizational routines, and the forms of visibility, which support and give meaning to decision making". Another example of the performative qualities of the everyday language can be drawn from Crowther et al. (2006, p. 180) who argue that "annual accounts can be considered as an important medium through which organizations seek to concentrate their public's attention on particular key messages". In this case, annual reports mediate a certain representation of the organization as an attempt to manage meaning, i.e. to "affect the company's public image and reputation by offering explanations, rationalizations and legitimation of its activities" (Aerts, 2001, pp. 3-4; Boje \& Rosile, 2008).

The narrative of the annual report, which is the focus of this study, is well covered in previous research on the discourse of accounting, especially concerning the CEO letter to shareholders (Aerts \& Yan, 2017; Amernic, Craig \& Tourish, 2007; Bartlett \& Chandler, 1997; Beattie, 2014; Craig \& Amernic, 2008; Hadro, Klimczak \& Pauka, 2017; Hooghiemstra, 2010; Hyland, 1998; Smith \& Taffler, 2000). A narrative consists of several rhetorical figures, devices and components that takes part in the shaping of the text as a whole. The tendency to emphasize good news and obfuscate bad as well as to attribute positive outcomes to internal factors and negative outcomes to external causes are common rhetorical characteristics of the annual report (Aerts, 1994; Brennan \& Conroy, 2013; Cho, Roberts, \& Patten, 2010; Clatworhty \& Jones, 2003; Conaway \& Wardrope, 2010; Merkl-Davies \& Brennan, 2007; Neu, Warsame, \& Pedwell, 1998; Poole, 2016). Buzzwords are also used to a larger extent than negatively charged words (Hildebrandt \& Snyder, 1981; Rutherford, 2003, 2005), and annual report texts are often written in difficult prose (Courtis, 1995, 2004; Li, 2008).

Other studies have focused on components of the narrative, for instance retrospective sense-making by use of linguistic accounts, such as excuses and justifications, in order to discursively handle external evaluations and critique (Aerts, 2005; Brühl \& Kury, 2019; Erickson, Weber \& Segovia, 2011; Sandell \& Svensson, 2016; 2017), and on the handling of uncertain- 
ty by the mitigation of knowledge claims through linguistic hedging (Klimczak, Dynel \& Pikos, 2016; Wang, Li \& Cao, 2012). Yet other studies have identified the use of metaphors in order to make annual report texts readable and meaningful (Walters-York, 1996). Bujaki \& McConomy (2012) suggest that metaphors have performative qualities as their use are related to decision making as well as to corporate performance.

Although there are company specific and unique messages in an annual report, the report also needs to be understood as a genre (Lupu \& Sandu, 2017; Rutherford, 2005, 2013; Sandell \& Svensson, 2016), i.e. as an institutionalized text operating in a predictable system of symbols with a certain style, form, terminology and formulations. Bhatia (2017) advocates both a critical perspective and the need to understand the interdiscursive construction of annual reports and other genres within financial communication. Bhatia defines interdiscursivity as "the function of appropriation of generic resources, primarily contextual in nature, focusing on specific relationships between and across discursive and professional practices as well as professional cultures" (Bhatia, 2010 p. 33). The production of an annual report is a specialized professional practice with encounters of discourses such as accounting, finance, management, PR and law. The perspective of Bhatia is critical genre analysis, which can be seen as a combination of genre analysis and critical discourse analysis. The critical perspective takes into account the cultural practice and the professional practice, not necessarily power and dominance. The goal is rather to "explain, clarify and 'demystify' professional practice" (Bhatia, 2017, p. 9) and has e.g. been applied to management texts (Björkvall, 2018). This is also our point of departure a genuine and unprejudiced curiosity.

The genre of the annual report is strictly regulated, for instance by means of a standardized conceptual apparatus, measurement and evaluation principles. Texts in annual reports are reused and reproduced in a process that can be referred to as discursive isomorphism (cf. DiMag- gio \& Powell, 1983), a process that tends to homogenize the everyday language of the report. This tendency to reproduce and prevail the hegemonic truths (or myths) are stronger when texts are produced within a specific genre (Phillips, Lawrence \& Hardy, 2004). This is not least due to the annual report writing process which includes a fuzzy and complex collective authorship (Gibbins, Richardson \& Waterhouse, 1990; Rahm \& Sandell, 2016), where large bodies of texts are produced within a short time frame. The narrative of the annual report is constructed by various mechanisms of intertextuality and interdiscursivity - traces of other texts, such as laws, standards, annual reports from the own company as well as from other companies shape the annual report narrative (Bhatia 2010, 2017; Lupu \& Sandu, 2017; Rahm \& Sandell, 2016). It is fair to say that texts produced for annual reports to some extent are consequences of institutionalized language use, to some extent intended neutral descriptions, i.e. incremental information, and to some extent impression management, i.e. attempts to control the impressions others form (Leary \& Kowalski, 1990, p. 34). Brennan \& Conroy (2013) also found indications of narcissism and hubris, i.e. texts not intentionally written to deceive but where the text rather is the outcome of self-deception and egocentricity

In summary, previous studies have acknowledged that the use of everyday language in annual reports partakes in the construction of world-views, legitimacy and social acceptance from the perspective of the individual company (Coupland, 2006; Craig \& Amernic, 2004; Vollmer, Mennicken \& Preda, 2009).

Our study aims at contributing to this literature by means of exploring the ways in which corporate annual reports - in their descriptions of the value of goodwill - express corporate dreams as part of the company's ongoing self-narration which, in turn, contributes to the building of legitimacy and trust.

Although some parts of the annual report narrative are well explored in research, less attention has been given to the narratives in the regulated part of the 
report which we study in this paper. There are reason to believe that the everyday language in the regulated part of the report differs from the language in voluntary, or at least less regulated parts. Aerts \& Yang (2017) for instance found that the texts in the letter to shareholders to a large extent is decoupled from the company specific financials. Even though the annual report heavily leans toward the retrospective, at least one section - normally a part of the footnote on intangible assets - allows for some prospective and visionary language: the description of goodwill.

\section{The narrated dream}

In this paper we are broadly inspired by narrative theory (e.g. Czarniawska, 2004; Gabriel, 1998). The narrative approach to organizational (and financial) communication emphasizes the importance of storytelling and narrative practices in organizations' attempts to communicate externally as well as internally. Simply put, the basic assumption of narrative theory is that narratives - and as these are enacted in the practice of storytelling - fulfil a crucial role in the reproduction and maintenance of groups, communities and culture. As suggested by Czarniawska (2004, p. 3), narratives can be considered the "most typical form of social life". We tell stories to each other and the stories contain knowledge, cultural values and moral points that are necessary in order to reproduce social order.

Not surprisingly, narratives and storytelling are also important elements in organizational communication. As pointed out by Gabriel, "it is now widely agreed that stories create, sustain, fashion and test meanings in and out of organizations" (Gabriel, 1998, p. 85). Moreover, stories are one of the means constructing organizations on an everyday basis. Stories clarify and display social relations and distribution of power within a certain organizational setting. Corporate storytelling is important in various organizations and contribute to legitimation of e.g. ideas of the organization (Rehnberg, 2014). Rehn- berg suggests the notion strategic storytelling in order to depict the different functions of the narratives, both strategic narratives (to create the brand) and co-created narratives (created by various stakeholders within and outside the organisation).

Dreams about the future are a particularly interesting case of organizational narratives. The dream, like the myth or saga (Salzer-Mörling, 1998), is a narratively structured way of expressing values, ideologies and moral points. Arguably, dreams exists only, at least in practical discourse, in the form of narratives, as responses to wishes such as: "Tell me about your dreams!". Put differently, dreams are necessarily narrated when they appear in social situations. Drawing upon this argument, we approach the annual reports as documents in which dreams are narrated - explicitly and implicitly.

Further, we suggest that the dreams told in annual reports can and should be seen as part of what is sometimes labelled self-narrative. Self-narratives are commonly understood as retrospective accounts "of the relationship among self-relevant events across time. In developing a self-narrative, we establish coherent connections along life events" (Gergen, 1994, p. 187). The self-narrative is commonly used in order to understand the ways in which people organize their past. However, in this paper we will specifically conceive of the dream as a self-narrative. The self-narrative is a story that, directly or indirectly, deals with the self, i.e. the ideal image of the self. When organizations tell stories they are also - in effect - narrating themselves. The story told reflects, as it were, the story-teller's ideal self-image. As Gergen (1994, p. 188) suggests "self-narratives function much like oral histories or morality tales within a society. They are cultural resources that serve such social purposes as self-identification, self-justification, self-criticism, and social solidification."

Through the self-narratives, organizations engage in self-justification and, in the long run, the production of trustworthiness. Telling appropriate stories is 
a way of showing allegiance to the socially accepted values in certain social contexts. In our view, the corporate dream is a case in point of such a self-narrative. In narrating appropriate corporate dreams, organizations publicly subscribe to legitimate value systems, which in turn can contribute to the production and maintenance of trustworthiness on the market as well as in society at large.

Corporate dreams should not be understood as unrealistic or psychotic fantasies without connection to reality and real life. You do not wake up from the corporate dreams; they are nothing less than part and parcel of business life and the value-system upon which this world is based. Corporate dreams - at least the appropriate ones, i.e. the ones socially accepted are stories depicting the value systems and moral premises undergirding the capitalist logic within which companies operate. In that sense the corporate dreams we analyze in this paper should be understood as legitimate ideals that companies are expected to strive for. The corporate dreams are culturally rooted and anchored as part of a common capitalistic narrative which gives both meaning and legitimacy to everyday actions within organizations and to the decision making of managers.

The corporate dreams should also be conceived of as institutionalized dreams, in other words commonly accepted in the form of presuppositions of what companies are, what companies do and should do. Presuppositions are most important when it comes to constructing a certain ideology as "relations of power are best served by meanings that are widely taken as given" (Fairclough, 2003, p. 58).

\section{Methodology}

The data corpus consists of the goodwill descriptions provided in the notes to the audited financial statements in annual reports from 2005 to 2010 from NASDAQ OMX Stockholm. These companies are since 2005 required to prepare their consolidated financial statements in accordance with International Financial
Reporting Standards (IFRS), adopted pursuant to Regulation (EC) No 1606/2002), including IFRS 3 Business Combinations. The number of annual reports studied are 1323, containing 589 goodwill descriptions of in total 14174 words. Thus, the average length of a commentary is 24 words. The longest explanation consists of 144 words, and the shortest of 5 words. The $589 \mathrm{com}$ mentaries emanate from the annual reports of 142 companies that at least on one occasion has disclosed a comment explaining recognised goodwill (see table 1 for a summary of the data).

Table 1: Description of sample and data

\begin{tabular}{lr}
\hline & $2005-2010$ \\
\hline Number of annual reports examined & 1323 \\
Number of companies providing explanations & 142 \\
Number of explanations provided & 589 \\
Text corpus word count & 14174 \\
Average length of explanation (words) & 24 \\
\hline
\end{tabular}

When analysing the goodwill descriptions, we have focused on the text rather than on the authors' intention or readers understanding of the text. The texts as such perform regardless of the intention behind it. Readers, being a diverse group not fully understood or defined (Stanton \& Stanton, 2002), might understand a text in very different ways between themselves, and in very different ways compared to what the author intends to communicate (Lewin, 2005; Rutherford, 2005). We handle these complications, as suggested by Myers (1989), by studying features of the text, the text functioning as an intermediary in an ongoing dialogue between authors and readers. Our analysis has been performed on original texts in Swedish in order to reduce risk of translation losses in the analytical process (cf. Evans, 2004). The annual reports studied are in most cases originally written, edited and revised in Swedish. In all cases both a Swedish version and an English version of the annual report are published simultaneously at the websites of the Swedish companies. The production in English is partly a parallel 
process, partly a translation of the Swedish version. Thus, in general we deem the English versions to be equivalent with Swedish versions. The examples are rendered from the English versions.

The 589 goodwill comments were analysed and discussed through close readings by the three authors. The thematic categorization was governed by data, thus a result of repeated interpretations, comparisons, classifications, groupings and mappings. In order to avoid restrictions of possible interpretations of the descriptions, no predefined categories were used. This means that the empirical data governed the categorization process (cf. Charmaz, 2006, p. 39). Relevant excerpts and formulations were selected, organized and thematised according to resemblance patterns. Broad categories were generated that subsequently developed into the three main types of dreams that we will explore in detail in what follows. To sum up - data brought the analysis to theoretical categories, theoretical categories were not applied to data.

\section{Corporate dreams}

In this section three corporate dreams will be discussed: the colonial dream, the evolutionary dream and the efficiency dream. The colonial dream expresses a vision of geo-political dominance whereas the evolutionary dream depicts a progressive future. The efficiency dream is a dream about the optimal usage of resources and the creation of the ultimately optimal organization.

\subsection{The colonial dream}

The colonial dream is built upon the narrative of increasing geo-political dominance. Historically, geo-political power has been exercised through more or less violent conquests of new territorial space. In the corporate world, the colonial dream takes the form of market domination in (potentially) profitable regions of the world. A central theme in the discourse of international business is the importance of being present in potentially profitable regions all over the world. The colonial dream is manifested in various ways in the annual reports subjected to study. In our first example, from the Swedish bank Handelsbanken, the phrase geographical proximity is an indication:

\begin{abstract}
The goodwill arising from the acquisition is mainly due to the synergy effects with Handelsbanken's established operations in Denmark, personnel-related resources, trademarks and the value of geographical proximity in the area where Lokalbanken runs its operations. (Handelsbanken, 2008, p. 71, emphasis added)
\end{abstract}

This excerpt can be interpreted as a selfnarrative containing the aspiration to expand already existing colonies or established operations. The noun operation is used ambiguously as the acquired bank runs its operations which of course refers to customer contacts but also to operations in the sense of competing with other banks about influence and power of the Danish territory.

In the excerpt below the adjective geographical is combined with the noun coverage, which is a way of allying with a general colonial narrative so as to display the appropriate aspiration for dominance and control:

\begin{abstract}
Securitas has acquired all shares in the security services company Claw Protection Services in South Africa, following the strategy to increase global presence. Claw Protection Services has approximately 800 employees and specializes in guarding services, mainly in the areas of Johannesburg and Pretoria. The company had at the time of acquisition projected annual sales of approximately MSEK 38. Goodwill, which amounts to MSEK 10.1 , is mainly related to geographical coverage and operational_expansion. (Securitas, 2010, p. 116, emphasis added)
\end{abstract}

Furthermore, the phrase operational expansion is used as a way of expressing hope for the future in the language of colonialism. More specifically, the value of 
goodwill is described as an investment in the future growth of the company with the purpose of expanding the revenue and the profit as well as establishing controllable geographical areas. This is a self-narrative that is not only about the willingness to cover an area, but also about increasing influence and power. The ultimate goal is expressed in the verb phrase increase global presence. The aspiration, the appropriate aspiration that is, for control over important areas where the companies strive for increased control of the revenues, bears resemblances with former colonial projects. The Suez Canal Company is an illustrative example, founded as a private enterprise in 1858 with the objective to construct the canal, an objective which was fulfilled in 1869. The ownership was British and French in order to avoid conflicts with the colonial ambitions of Great Britain and France. The Suez Canal remained property of the Suez Canal Company with powerful military British support until the Egyptian nationalization in 1956. This company is the most obvious example of living the colonial dream with intertwined connections between economic, political and military power, control and dominance.

Another way of writing about expansive aspirations in annual reports is to emphasize growth beyond national borders. Consider the following example:

Goodwill amounted to 97 and consists of assembled work force, future market shares and synergies. This acquisition strengthens the SKF Group's position in industrial seals by bringing to the Group new products and new technologies. Geographically, SKF Group's global organisation will also be able to bring Macrotech's products to markets outside North America. (SKF, 2006, p. 46, emphasis added)

In this example, the global organisation is emphasized as the instrument by which the corporate expansion will be undertaken. This way of presenting resembles the global ambitions of colonial powers in the $19^{\text {th }}$ century or contemporary neocolonial attempts to control the world by USA, Rus- sia and China. Also, neocolonialism entails corporation between political power and the companies in foreign countries such as USA and US companies in Latin America, Asia and Africa.

\subsection{The evolutionary dream}

The evolutionary dream is, like the colonial dream, associated with expansion but also with the companies' development into a state of higher quality and stronger persistence. The origin of the evolutionary dream can be traced to the general encyclopedic formulations "the gradual development of something" and "the process by which different kinds of living organism are believed to have developed from earlier forms during the history of the earth" (Waite, 2015). The evolutionary dream informs a self-narrative in which the wellknown noun phrase the survival of the fittest coined by Charles Darwin becomes a central moral guideline. Organizational and industrial development are central tenets within management discourse. The link between biology and society leads back to the $19^{\text {th }}$ century and connects with colonialism as well as with our contemporary perception:

\begin{abstract}
Darwin's general theory of evolution claims that natural species evolve through variation and natural selection, a process that is not necessarily progressive. However, in the evolutionary theory espoused by Victorian social scientists, human societies were bound to improve, change was progressive, and led to further civilization and moral improvement of human society. Such theories were central to the $19^{\text {th }}$-century approach to society and political life. They underpinned colonialism and are still deeply entrenched in Western thought. (Scott \& Marshall, 2009, p. 233)
\end{abstract}

The evolutionary dream is a dream about eternal growth. It is also an expression of an aspiration for the never-ending development of the organization and the products in order to survive in the market competition. Such an aspiration can materialize itself in continuing amendments of products as a way of adapting to changed 
environments and modulation of functions. Elekta's acquisition of Medical Intelligence, commented on below, is a case in point:

Goodwill refers to future synergy effects. The acquisition provides the possibility of developing more integrated products in the near future that supplement and strengthen Elekta's solutions for image guided and stereotactic radiation therapy. Elekta's international sales organizations will facilitate sales and market penetration. (Elekta, 2005/06, p. 33, emphasis added)

The speed of the evolution can increase possibility of developing more integrated products; sales and market penetration when developed in symbiosis between the acquiring and the acquired company. Growth and development are often depicted as a result of increased knowledge in the corporative organization as in this example from $\mathrm{H} \& \mathrm{M}$ :

Goodwill arising from the acquisition relates to synergy effects etc. achieved due, among other things, to economies of scale in production, logistics, expansion and know-how in the existing organisation. (H\&M, 2008, p. 28, emphasis added)

H\&M's acquisition is here motivated by the access to valuable tacit knowledge, know-how, in the existing organisation of the company added to the assets of H\&M. The idea seems to be that know-how can contribute to the growth, the evolution of H\&M. The crux of evolutionary processes is adopting to a variable and changing world, which calls for a need of ongoing evolution in terms of new knowledge. A prerequisite for this successful evolution is the skill of existing employees which is the key phrase in the comment by MTG below:

The goodwill in 2010 comprise of potential new products and customers expected to be realised in future as well as the skill of existing employees. (MTG, 2010, p. 74, emphasis added)
Thus, knowledge is not described as an abstract and general resource but very much connected to concrete individuals and groups. The acquisition of the company, then, is motivated by the access to these persons as well as their knowledge and competences.

\subsection{The efficiency dream}

The efficiency dream is rooted in the aspiration to optimize the relation between input and output. To present oneself as an efficient organization, references to different notions of performance are called for. An efficient organization can be described - or narrated - in terms of a slim machine "achieving maximum productivity with minimum wasted effort or expense" but also in terms of an organization "working in a well-organized and competent way" (Waite, 2015). Both of these meanings seems to have relevance for the efficiency dream.

Arguably, efficiency is one of the strongest contemporary ideals and, consequently, an appropriate aspiration for companies as well as other kind of organizations. Put differently, organizations have to show allegiance to the efficiency dream in different ways. Ratos' annual report 2007 offers an illustrative example, motivating goodwill from the acquisition of EuroMaint in the key formulation to continuously develop and improve the efficiency:

\begin{abstract}
The goodwill recognised for EuroMaint represents a well-functioning organization with the ability to continuously develop and improve the efficiency of its operations, make profitable agreements, a business model that generates strong cash flows and a leading market position as well as intangible assets that cannot be identified and measured separately from goodwill. (Ratos, 2007, p. 62, emphasis added)
\end{abstract}

The expectation of increased future efficiency is further spelled out by hopes and desires to make profit, a steady cash flow and to obtain a leading market position. However, the dream of efficiency is mainly expressed in terms of coordination and in- 
tegration of resources and activities. Let us return to an example from $\mathrm{H} \& \mathrm{M}$ discussed above:

Goodwill arising from the acquisition relates to synergy effects etc. achieved due, among other things, to economies of scale in production, logistics, expansion and know-how in the existing organisation. (H\&M, 2008, p. 28, emphasis added)

$\mathrm{H} \& \mathrm{M}$ describes the synergy effects emanating from economies of scale made possible through the acquisition. Hence, synergy is here not only an expression for a dream about a successful evolution (see the previous section) but also a way to display a dream of efficiency. Furthermore, in the extract from Kinnevik below, economies of scale are mentioned as a way of eliminating redundant and unnecessary activities, which at the end of the day is assumed to result in reduced costs:

Goodwill, in connection with the acquisition of Frövi, pertains to Korsnäs' expectation of strengthening its position in the market for Liquid Packaging Board and Folding Carton and the expectation of receiving economies of scale, which would result in reduced costs when Frövi is integrated into Korsnäs' existing operations. (Kinnevik, 2006, p. 42, emphasis added)

One plus one, according to this logic, equals three; more can be achieved with less resources. Economies of scale is a notion used in business discourse to present oneself as a trustworthy company, one that displays an aspiration to be and remain efficient.

\section{Conclusion: Corporate dreams, moral tales and trust}

In this paper, we have showed how the management of the company is both source and owner of the text and how the dreams, hopes and fears are expressed in the content, phrases and emphases chosen for the goodwill commentaries. The three dreams discussed above have something to say about the demands facing companies in contemporary capitalism. The self-narratives also involve moral elements, and as such they operate as a kind of moral tales (Baruch, 1981). Writing about oneself in terms of the dreams about the future is also a way of responding to an institutionalized moral order. That is, presenting oneself as a morally justifiable - and trustworthy - organization is one of the ways in which organizations try to secure their survival. Thus, the public dreaming about colonialization, evolution and efficiency displays a sense of corporate rationality, which is a crucial element of the moral of the market and, consequently, part of the trust capital of a company. The dreams are not necessarily pleasant or generally (cf. the colonial dream), but they are dreams that belong to the world of companies, markets and capitalism. These dreams are appropriate and trustworthy dreams. One reason for this is the overall meta-narrative that the three corporate dreams refer to, namely the narrative of instrumental power, more specifically the aspiration to tame and control the unpredictable future. The colonial dream is about geopolitical dominance. The evolutionary dream refers to the intellectual and technological superiority. The dream of efficiency stems from the desire to take lead by means of being the smartest, fittest and leanest.

The meta-narrative of instrumental power is one of the cornerstones of the very discourse of management. The notion of management stems from Italian 'training of a horse; action and paces of a horse' and came into English in the $16^{\text {th }}$ century (Waite, 2015). The wild and unruly could be about the will and interests of the employees, the desire and motivation of the consumers, the unpredictable markets etc. This is not entirely surprising one might argue. The idea of management presupposes ideas of controlling one's destiny and reducing the dependency on luck and fate. Expanding the borders within which the company operates is at the heart of the definition of the company within a capitalist system where growth is required 
for survival. The anti-thesis to the company is an organization that does not move or, even worse, that decline. By means of presenting legitimate dreams, dreams that represent appropriate aspirations for the future, companies partake in the rhetorical building of trustworthiness, not only for the individual company but also, at least on a collective scale, for capitalism as such.

\section{References}

Aerts, W. (1994). On the use of accounting logic as an explanatory category in narrative accounting disclosures. Accounting, Organizations and Society, 19(4-5), 337-353.

Aerts, W. (2001). Inertia in the attributional content of annual accounting narratives. European Accounting Review, 10(1), 3-32.

Aerts, W. (2005). Picking up the pieces: Impression management in the retrospective attributional framing of accounting outcomes. Accounting, Organizations and Society, 30(6), 493-517.

Aerts, W., \& Yan, B. (2017). Rhetorical impression management in the letter to shareholders and institutional setting: A metadiscourse perspective. Accounting, Auditing \& Accountability Journal, 30(2), 404-432.

Amernic, J., Craig, R., \& Tourish, D. (2007). The transformational leader as pedagogue, physician, architect, commander, and saint: Five root metaphors in Jack Welch's letters to stockholders of General Electric. Human Relations, 60(12), 1839-1872.

Arnold, P. J., \& Oakes, L. S. (1998). Accounting as discursive construction: The relationship between statement of financial accounting standards no. 106 and the dismantling of retiree health benefits. Accounting, Organizations and Society, 23(2), 129-153.

Bartlett, S. A., \& Chandler, R. A. (1997). The corporate report and the private shareholder: Lee and Tweedie twenty years on. The British Accounting Review, 29(3), 245-261.

Baruch, G. (1981). Moral tales: Parents' stories of encounters with the health professions. Sociology of Health \& Illness, 3(3), 275-295.

Beattie V. (2014). Accounting narratives and the narrative turn in accounting research:
Issues, theory, methodology, methods and a research framework. British Accounting Review, 46, 111-134.

Bhatia, V. K. (2010). Interdiscursivity in professional communication. Discourse \& Communication, 21(1), 32-50.

Bhatia, V. K. (2017). Critical genre analysis: Investigating interdiscursive performance in professional practice. Abingdon, Oxon: Routledge.

Björkvall, A. (2018). Critical genre analysis of management texts in the public sector: Towards a theoretical and methodological framework. In D. Wojahn, C. Seiler Brylla, \& G. Westberg (Eds.), Kritiska text-och diskursstudier (pp. 57-79). Huddinge, Sweden: Södertörns högskola.

Boje, D. M., \& Rosile, G. A. (2008). Specters of Wal-Mart: A critical discourse analysis of stories of Sam Walton's ghost. Critical Discourse Studies, 5(2), 153-179.

Brennan, N. M., \& Conroy, J. P. (2013). Executive hubris: The case of a bank CEO. Accounting, Auditing \& Accountability Journal, 26(2), 172-195.

Brennan, N. M., Merkl-Davies, D. M., \& Beelitz, A. (2013). Dialogism in corporate social responsibility communications: Conceptualising verbal interaction between organisations and their audiences. Journal of Business Ethics, 115(4), 665-679.

Brühl, R., \& Kury, M. (2019). Rhetorical tactics to influence responsibility judgments: Account giving in banks presidents' letters during the financial market crisis. International Journal of Business Communication, 56(3), 299-325.

Bujaki, M., \& McConomy, B. (2012). Metaphor in Nortel's letters to shareholders 19972006. Accounting, Auditing \& Accountability Journal, 25(7), 1113-1139.

Charmaz, K. (2006), Constructing grounded theory: A practical guide through qualitative analysis. London: Sage.

Cho, C. H., Roberts, R. W., \& Patten, D. M. (2010). The language of US corporate environmental disclosure. Accounting, Organizations and Society, 35(4), 431-443.

Clatworthy, M., \& Jones, M. J. (2003). Financial reporting of good news and bad news: evidence from accounting narratives. Accounting and Business Research, 33(3), 171-185. 
Conaway, R. N., \& Wardrope, W. J. (2010). Do their words really matter? Thematic analysis of US and Latin American CEO letters. The Journal of Business Communication, 47(2), 141-168.

Coupland, C. (2006). Corporate social and environmental responsibility in web-based reports: Currency in the banking sector? Critical Perspectives On Accounting, 17(7), 865-881.

Courtis, J. K. (1995). Readability of annual reports: Western versus Asian evidence. Accounting, Auditing \& Accountability Journal, 8(2), 4-17.

Courtis, J. K. (2004). Corporate report obfuscation: artefact or phenomenon? The British Accounting Review, 36(3), 291-312.

Craig, R. J., \& Amernic, J. H. (2004). Enron discourse: The rhetoric of a resilient capitalism. Critical Perspectives On Accounting, 15(6-7), 813-852.

Craig, R., \& Amernic, J. (2008). A privatization success story: Accounting and narrative expression over time. Accounting, $\mathrm{Au}$ diting \& Accountability Journal, 21(8), 1085-1115.

Crowther, D., Carter, C., \& Cooper, S. (2006). The poetics of corporate reporting: Evidence from the UK water industry. Critical Perspectives On Accounting, 17(2-3), 175-201.

Czarniawska, B. (2004). Narratives in social science research. London: Sage.

DiMaggio, P., \& Powell, W. W. (1983). The iron cage revisited: Collective rationality and institutional isomorphism in organizational fields. American Sociological Review, 48(2), 147-160.

Erickson, S. L., Weber, M., \& Segovia, J. (2011). Using communication theory to analyze corporate reporting strategies. The Journal of Business Communication, 48(2), 207-223.

Evans, L. (2004). Language, translation and the problem of international accounting communication. Accounting, Auditing \& Accountability Journal, 17(2), 210-248.

Fairclough, N. (2003). Fairclough, N. (2003). Analysing discourse: Textual analysis for social research. New York: Routledge.

Gabriel, Y. (1998). Same old story or changing stories? Folkloric, modern and postmodern mutations. In: D. Grant, T. Keenoy, \& C.
Oswick (Eds.). Discourse and organization (pp. 84-103). London: Sage.

Gergen, K. J. (1994). Realities and relationships: Soundings in social construction. Cambridge: Harvard University Press.

Gibbins, M., Richardson, A., \& Waterhouse, J. (1990). The management of corporate financial disclosure: Opportunism, ritualism, policies, and processes. Journal of Accounting Research, 28 (1), 121-143.

Gu, F., \& Lev, B. (2011). Overpriced shares, ill-advised acquisitions, and goodwill impairment. The Accounting Review, 86(6), 1995-2022.

Gynther, R. S. (1969). Some "conceptualizing” on goodwill. The Accounting Review, 44(2), 247-255

Hadro, D., Klimczak, K. M., \& Pauka, M. (2017). Impression management in letters to shareholders: Evidence from Poland. Accounting in Europe, 14(3), 305-330.

Hildebrandt, H. W., \& Snyder, R. D. (1981). The Pollyanna hypothesis in business writing: Initial results, suggestions for research. The Journal of Business Communication, 18(1), 5-15.

Hines, R. D. (1988). Financial accounting: In communicating reality, we construct reality. Accounting, Organizations and Society, 13(3), 251-261.

Hooghiemstra, R. (2010). Letters to the shareholders: A content analysis comparison of letters written by CEOs in the United States and Japan. The International Journal of Accounting, 45(3), 275-300.

Hyland, K. (1998). Exploring corporate rhetoric: Metadiscourse in the CEO's letter. The Journal of Business Communication, 35(2), 224-244.

International Financial Reporting Standard 3 (IFRS 3) (2013). In FAR akademi, IFRS2013 [10 ${ }^{\text {th }}$ updated edition. $]$. Stockholm: FAR akademi.

King, D. R., Dalton, D. R., Daily, C. M., \& Covin, J. G. (2004). Metaa-analyses of post-acquisition performance: Indications of unidentified moderators. Strategic Management Journal, 25(2), 187-200.

Klimczak, K. M., Dynel, M., \& Pikos, A. (2016). Goodwill impairment test disclosures under uncertainty. Journal of Accounting and Management Information Systems, 15(4), 639-660. 
Leary, M. R., \& Kowalski, R. M. (1990). Impression management: A literature review and two-component model. Psychological Bulletin, 107(1), 34-47.

Lewin, B. A. (2005). Hedging: an exploratory study of authors' and readers' identification of 'toning down' in scientific texts. Journal of English for Academic Purposes, 4(2), 163-178.

Li, F. (2008). Annual report readability, current earnings, and earnings persistence. Journal of Accounting and Economics, 45(2-3), 221-247.

Lupu, I., \& Sandu, R. (2017). Intertextuality in corporate narratives: A discursive analysis of a contested privatization. Accounting, Auditing \& Accountability Journal, 30(3), 534-564.

Ma, R., \& Hopkins, R. (1988). Goodwill - An example of puzzle solving in accounting. Abacus, 24(1), 75-85.

Merkl-Davies, D. M. \& Brennan, N. M. (2007). Discretionary disclosure strategies in corporate narratives: Incremental information or impression management? Journal of Accounting Literature, 27(1), 116-196.

Ministry of Justice (2005), SFS (Swedish Code of Statutes) 2005:551. Aktiebolagslagen 2005 [The Swedish Companies Act]. Svensk författningssamling (1825-2018). Stockholm: Svensk författningssamling. Retrieved from https://tinyurl.com/y787129a.

Moeller, S. B., Schlingemann, F. P., \& Stulz, R. M. (2005). Wealth destruction on a massive scale? A study of acquiring firm returns in the recent merger wave. The Journal of Finance, 60(2), 757-782.

Morgan, G. (1988). Accounting as reality construction: Towards a new epistemology for accounting practice. Accounting, Organizations and Society, 13(5), 477-485.

Myers, G. (1989). The pragmatics of politeness in scientific articles. Applied Linguistics, 10(1), 1-35.

Neu, D., Warsame, H., \& Pedwell, K. (1998). Managing public impressions: Environmental disclosures in annual reports. Accounting, Organizations and Society, 23(3), 265-282.

Phillips, N., Lawrence, T. B., \& Hardy, C. (2004). Discourse and institutions. Academy of Management Review, 29(4), 635-652.
Poole, R. (2016). Good times, bad times: A keyword analysis of letters to shareholders of two Fortune 500 banking institutions. International Journal of Business Communication, 53(1), 55-73.

Power, M. K. (2003). Auditing and the production of legitimacy. Accounting, Organizations and Society, 28(4), 379-394.

Prakash, P., \& Rappaport, A. (1977). Information inductance and its significance for accounting. Accounting, Organizations and Society, 2(1), 29-38.

Rahm, H., \& Sandell. N. (2016). Att legitimera priset på förvärvat företag: Intertextuella förhållanden i goodwillformuleringar [Legitimizing the price of business acquisitions: Intertextual relations in goodwill comments]. Sakprosa, 8(3), 1-33.

Rehnberg, H. S. (2014). Organisationer berättar: narrativitet som resurs $i$ strategisk kommunikation [When organizations tell stories: Narrativity as a resource in strategic communication]. Uppsala: Institutionen för nordiska språk. Södertörn doctoral dissertations.

Roll, R. (1986). The hubris hypothesis of corporate takeovers. Journal of Business, 59(2), 197-216.

Rutherford, B. A. (2003). Obfuscation, textual complexity and the role of regulated narrative accounting disclosure in corporate governance. Journal of Management and Governance, 7(2), 187-210.

Rutherford, B. A. (2005). Genre analysis of corporate annual report narratives: A corpus Linguistics-based approach. The Journal of Business Communication, 42(4), 349-378.

Rutherford, B. A. (2013). A genre-theoretic approach to financial reporting research. The British Accounting Review, 45(4), 297-310.

Salzer-Mörling, M. (1998). As god created the earth ... A saga that makes sense? In D. Grant, T. Keenoy, \& C. Oswick (Eds.), Discourse and organization (pp. 104-118). London: Sage.

Sandell, N., \& Svensson, P. (2016). The language of failure: The use of accounts in financial reports. International Journal of Business Communication 53(1), 1-22.

Sandell, N., \& Svensson, P. (2017). Writing writedowns: The rhetoric of goodwill impairment. Qualitative Research in Accounting and Management, 14(1), 81-102. 
Scott, J. \& Marshall, G. (2009). A dictionary of sociology (3rd rev. ed.). New York: Oxford University Press.

Seetharaman, A., Balachandran, M., \& Saravanan, A. S. (2004). Accounting treatment of goodwill: Yesterday, today and tomorrow: Problems and prospects in the international perspective. Journal of Intellectual Capital, 5(1), 131-152.

Smith, M., \& Taffler, R. J. (2000). The chairman's statement - A content analysis of discretionary narrative disclosures. Accounting, Auditing \& Accountability Journal, 13(5), 624-647.

Stanton, P., \& Stanton, J. (2002). Corporate annual reports: Research perspectives used. Accounting, Auditing \& Accountability Journal, 15(4), 478-500.

Vollmer, H. (2007). How to do more with numbers: Elementary stakes, framing, keying, and the three-dimensional character of numerical signs. Accounting, Organizations and Society, 32(6), 577-600.
Vollmer, H., Mennicken, A., \& Preda, A. (2009). Tracking the numbers: Across accounting and finance, organizations and markets. Accounting, Organizations and Society, 34(5), 619-637.

Walters-York, L. M. (1996). Metaphor in accounting discourse. Accounting, Auditing \& Accountability Journal, 9(5), 45-70.

Waite, M. (Ed.) (2015). Oxford English dictionary [Electronic resource]. Oxford: Oxford University Press.

Wang, H., Li, L., \& Cao, J. (2012). Lexical features in corporate annual reports: A corpus-based study. European Journal of Business and Social Sciences, 1(9), 55-71.

Wiklund, J., \& Shepherd, D. A. (2009). The effectiveness of alliances and acquisitions: The role of resource combination activities. Entrepreneurship Theory and Practice, 33(1), 193-212. 